\title{
Digitale geletterdheid bij Vlaamse jongeren: hoe gaan ze om met onlinecontentrisico's?
}

\begin{abstract}
We onderzoeken welke onlinerisico's Vlaamse jongeren (15-19) lopen. We stellen vast dat een hoge mate van digitale geletterdheid samengaat met een hoge blootstelling aan internetrisico's. Jongeren met veel zelfvertrouwen komen vaker in contact met risicovolle online-inhoud. Een goede vertrouwensband met de ouders vermindert de kans op risicovolle blootstelling. Jongeren ondernemen weinig actie na een negatieve online-ervaring.
\end{abstract}

\section{Inleiding}

Internetgebruik bij jongeren is een actueel thema waar onderzoekers steeds meer aandacht voor hebben. Volgens vergelijkend Europees onderzoek uit 2008, surft 7I\% van de Belgische kinderen op het internet (Europese Commissie, 2008). In Vlaanderen maakt $86 \%$ van de 9 - tot 12 -jarigen en $96 \%$ van de 13 - tot 18 -jarigen gebruik van het internet. Vanaf hun elfde jaar gaan jongeren dagelijks het internet op. Jongens gebruiken het internet gemiddeld zo'n negen keer per week, meisjes zo'n zes keer per week (Vandercammen, 2006).

In tegenstelling tot wat volwassenen soms denken, zijn niet alle jongeren even vlotte en vaardige internetgebruikers. Digitale vaardigheden zijn (net zoals bij volwassenen) ongelijk verdeeld over de jongerenpopulatie, en hangen samen met sociodemografische kenmerken (Van Dijk, 2006). Kinderen uit hogere, socio-economische gezinnen en jongens beschikken over meer toegangsmogelijkheden, gaan frequenter online, en lijken meer voordeel te halen uit de kansen geboden door het internet (Livingstone \& Helsper, 2007).

Sofie Vandoninck is wetenschappelijk medewerker verbonden aan het Centrum voor Mediacultuur en Communicatietechnologie van de Katholieke Universiteit Leuven.Correspondentie aan de eerste auteur: Centrum voor Mediacultuur en Communicatietechnologie, Parkstraat 45 bus 3603, 3000 Leuven (België), tel: +32 I6 32 31 68, e-mail: sofie.vandoninck@soc.kuleuven.be. Prof. dr. Leen d'Haenens is hoogleraar verbonden aan het Centrum voor Mediacultuur en Communicatietechnologie van de Katholieke Universiteit Leuven. Dr. Verónica Donoso is senior onderzoeker verbonden aan het Centrum voor Mediacultuur en Communicatietechnologie van de Katholieke Universiteit Leuven. 
We stellen vast dat in de meeste landen, waaronder ook België, de meerderheid van de kinderen het educatieve en informatieve potentieel weten te benutten. Ook op vlak van amusement, sociale netwerken en ervaringen delen met anderen, maken kinderen gebruik van de mogelijkheden die het internet te bieden heeft. Als het echter gaat om complexe toepassingen, waarbij actieve participatie en creativiteit verwacht wordt, blijkt dat veel kinderen daar (nog) niet toe komen (Livingstone \& Helsper, 2007).

Het exploreren van de kansen die het internet te bieden heeft, hangt onvermijdelijk samen met de blootstelling aan onlinerisico's (Livingstone \& Helsper, 2009). Wanneer we specifiek kijken naar onlinerisico's, zien we dat jongens (9- tot I4-jarigen) virussen als het grootste onlinerisico beschouwen. Meisjes daarentegen zien chatten met een onbekende contactpersoon als het belangrijkste onlinegevaar. Andere internetrisico's die jongeren vermelden zijn open chatboxen, persoonlijke informatie online plaatsen en contact hebben met onbekenden (Europese Commissie, 2006). Ongeveer één op zes van de Vlaamse 9- tot I2-jarigen heeft zich al ooit bedreigd gevoeld online en $40 \%$ is al in contact gekomen met risicovolle online-inhoud, dat wil zeggen choquerende, gewelddadige, seksuele of racistische teksten of (video)beelden (Valcke, Schellens, Van Keer \& Gerarts, 2005). In dit onderzoek gaan we dieper in op de zogenaamde inhoudsrisico's (contentrisico's).

In vergelijking met de andere EU-landen, kan in België het internetgebruik van kinderen en jongeren beschouwd worden als 'gemiddeld' (tussen 65\% en $85 \%$ ).

Jongeren worden aangemoedigd om gebruik te maken van het internet en worden erop gewezen dat digitale vaardigheden essentieel zijn om hun weg te vinden in de informatiemaatschappij. Een intensiever gebruikspatroon betekent onvermijdelijk ook meer blootstelling aan risico's, en het zijn die risico's waar overheden, scholen, ouders en andere betrokkenen zich zorgen over maken. Het heeft geen zin om deze onlinerisico's te negeren of al te sterk te minimaliseren. Restrictief optreden biedt evenmin de gewenste impact omdat jongeren zich niet steeds houden aan restricties en omdat dit meteen ook een beperking legt op de onlinekansen waar jongeren gebruik van kunnen maken. Het lijkt meer zinvol om jongeren te ondersteunen zodat ze stevig in hun schoenen staan wanneer ze op de digitale snelweg navigeren en in staat zijn om onlinerisico's op een gepaste manier het hoofd te bieden. Overheden en industrie kunnen hiertoe zelfreguleringsmechanismen introduceren, en ouders, leerkrachten en andere opvoeders die zich bewust zijn van de problematiek kunnen kinderen de nodige ondersteuning bieden bij de ontwikkeling van gepaste strategieën om met onlinerisico's om te gaan (Staksrud \& Livingstone, 2009).

Het doel van dit onderzoek is een meer gedetailleerd beeld te krijgen van de (risicovolle) onlineactiviteiten van Vlaamse jongeren, hoe ze omgaan met deze onlinerisico's en welke factoren hierop een invloed hebben. Ten eerste gaan we na hoe digitaal vaardig de Vlaamse jongeren zijn en welke sociodemografische en persoon- 
lijkheidskenmerken de mate van digitale vaardigheid voorspellen. Ten tweede onderzoeken we in welke mate Vlaamse jongeren blootgesteld worden aan contentrisico's van commerciële, agressieve, seksuele en waardegerelateerde aard en welke jongeren het meest vatbaar zijn voor blootstelling aan onlinerisico's. Tot slot brengen we in kaart welke strategieën jongeren hanteren wanneer ze geconfronteerd worden met onlinerisico's en welke invloed ouders hierop kunnen hebben.

\section{Theoretische achtergrond}

Onderzoek naar digitale geletterdheid bij jongeren is nog relatief schaars. Aandacht naar de meerlagigheid van dit begrip is van recente datum. Digitale geletterdheid, ook wel 'internetgeletterdheid', ligt in de lijn van het concept mediageletterdheid, dat verwijst naar de vaardigheid van een individu om informatie te verzamelen, te analyseren, te evalueren en te creëren (Livingstone, 2004). Wij definiëren digitale geletterdheid vanuit de breedte en de diepte. Enerzijds zien we het als een palet aan capaciteiten van een individu om via ICT kennis en informatie te verkrijgen, deze kritisch te evalueren, die elementen te selecteren die relevant zijn, en zelf nieuwe inhoud te creëren. Anderzijds duidt het ook op de aard van het internetgebruik: een meer gesofistikeerd internetgebruik waarbij men inhoud creëert en via het internet actief participeert in de samenleving, wijst op een hogere mate van digitale geletterdheid (Livingstone \& Helsper, 2007). De frequentie van het internetgebruik, de mate waarin men gebruikmaakt van onlinekansen (gebruik van diverse toepassingen), en de zelf ingeschatte internetvaardigheden zijn indicatoren voor de digitale geletterdheid van een individu.

Uit verscheidene studies blijkt intussen dat jongeren geen homogene groep van internetgebruikers vormen. Leeftijd, geslacht en socio-economische groep van de ouders blijken ongemeen sterke voorspellers voor trends in ICT-gebruik. Het internet blijkt niet zoals verhoopt als een natuurlijke gelijkschakelende factor te opereren en dus dient de aandacht gericht te worden op de promotie van digitale geletterdheid en het adequaat tegengaan van mogelijk schadelijk gebruik van internettoepassingen. Het gebrek aan aandacht voor de digitale verschillen tussen groepen van kinderen en jongeren onderling vindt zijn oorsprong in de optimistische retoriek die Tapscott (I998) en anderen rond de zogenaamde digitale generatie hebben opgehangen. Hierbij wordt technofobie doorgaans geassocieerd met inflexibiliteit en conservatisme, terwijl creativiteit en spontaneïteit worden toegeschreven aan technofiele kinderen en jongeren.

Dergelijke visie staat in schril contrast met empirisch onderzoek waaruit een grote mate van differentiatie in ICT-gebruik en -vaardigheden bij kinderen en jongeren blijkt, zelfs bij eerder gelijke mate van toegang tot ICT. Leeftijdsverschillen worden gewoonlijk gezien als lineair: met de jaren vertoont men de neiging om meer 
onlinerisico's en kansen op te zoeken. Verschillen qua geslacht, SES en opleiding worden doorgaans gezien als sterk maar niet altijd even duidelijk voorspelbaar (Weiser, 2000). Met andere woorden, het niveau van digitale geletterdheid is een complexe materie waarbij naast sociodemografische, ook psychologische factoren (bijv. zelfbeeld, risicoperceptie) een rol spelen (Broos \& Roe, 2006). In het licht van die complexiteit, zullen wij in dit artikel de potentiële rol van sociodemografische en persoonlijkheidskenmerken op het niveau van digitale geletterdheid interpreteren vanuit een theoretisch kader dat de studie van de digitale kloof, de uses \& gratifications-traditie en de socialisatietheorie herbergt.

Inmiddels is gebleken dat de binaire definitie van de digitale kloof (nl. men is 'in-' of 'uitgesloten') een heilloze weg is. Veel zinvoller is het om de gradaties van digitale inclusie in kaart te brengen langs een continuüm van basisgebruikers tot meer gesofistikeerde gebruikers. Van Dijk (2006) stelt de ongelijke kansen ter discussie waarnaar de digitale kloof zou kunnen leiden. Hij maakt onderscheid tussen verschillen in materiële toegang en motivatie en verschillen in vaardigheden en gebruik. Een voorbeeld: hoewel het genderverschil in toegang in Noordwest-Europa en Noord-Amerika is weggewerkt, blijft een zogenaamde 'gender gap' overeind in die zin dat jongens meer gebruik lijken te maken van de kansen die het internet te bieden heeft, met name de meer complexe toepassingen die de nodige interactiviteit en creativiteit van de gebruikers impliceren. In dit licht is de zogenaamde 'ladder of online opportunities' van Livingstone en Helsper (2007) een nuttig analytisch instrument om de breedte en diepte van het gebruik van digitale technologie in kaart te brengen. Uit onderzoek blijkt dat jongeren die hoog scoren op digitale geletterdheid meer gebruikmaken van onlinekansen, en daardoor ook vaker in contact komen met onlinerisico's. Risico's zijn als het ware onvermijdelijk wil men zichzelf ontwikkelen tot een vaardige internetgebruiker. Beleidsmakers en opvoeders balanceren voortdurend tussen enerzijds het willen beschermen van kinderen tegen ongewenste inhouden, en anderzijds het willen respecteren van de autonomie, privacy en vrijheid van het kind. In het licht daarvan is het cruciaal om jongeren strategieën bij te brengen die hen helpen om met deze onlinerisico's om te gaan (zgn. coping-strategieën) en om de mogelijk schadelijke impact ervan te beperken (Staksrud \& Livingstone, 2009). De manier waarop de ouders tussenkomen in het internetgebruik van hun kinderen kan een impact hebben op de ontwikkeling van hun interventiestrategieën. Onderzoek wijst uit dat ouders die vaak gebruikmaken van het internet en zelf hoog scoren qua digitale vaardigheden, meer tussenkomen in het internetgebruik van hun kinderen. Ouders verkiezen doorgaans sociale interventies zoals praten over internetgebruik en samen achter de computer zitten boven louter restrictieve vormen van inmenging zoals een verbod om bepaalde toepassingen te gebruiken of het installeren van filtering- of monitoring-software (Livingstone \& Helsper, 2008). 
FIGUUR 1 Schematische weergave van het onderzoeksmodel

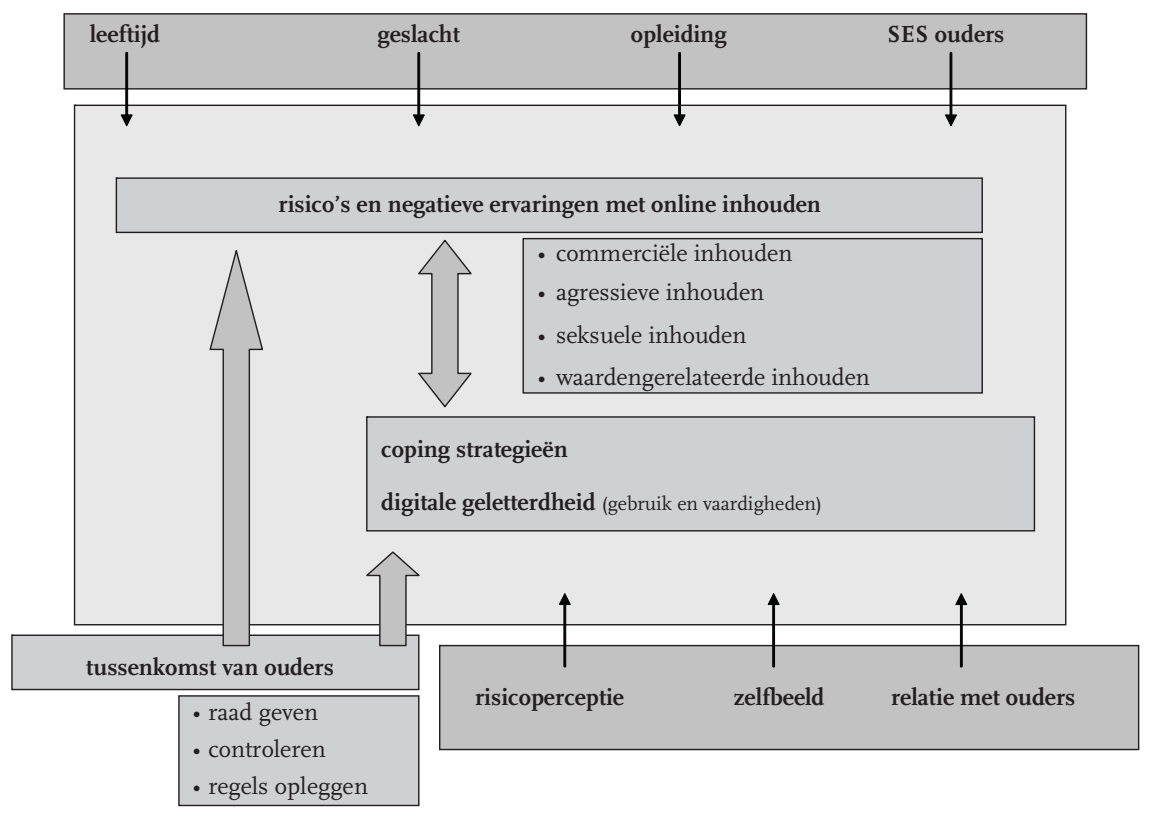

Digitale technologie wordt doorgaans gebruikt om behoeften en wensen te bevredigen. De uses \& gratifications-onderzoekstraditie richt zich op dié factoren die motieven voor mediagebruik en mediagerelateerd gedrag beïnvloeden (Newhagen \& Rafaeli, I996). Convergerende mediaplatforms vergemakkelijken bijvoorbeeld synchroon gebruik (zgn. 'multi-tasking'). Tot nog toe echter is het Europees onderzoek dat zich bezighoudt met motieven en onlinevaardigheden, diverse keuzes van toepassingen (of gebrek daaraan) onder jongeren relatief schaars gebleven. Daarom zijn pogingen om verschillende adoptiestijlen van jongeren te vatten vruchtbaar onderzoek gebleken. Het EU Kids Online-project (Livingstone \& Haddon, 2009) en in België het TIRO-onderzoek (Walrave, Lenaerts \& De Moor, 2008) zijn welkome aanvullingen op deze schaarste. De socialisatietheorie benadrukt het belang van sociale en culturele normen tijdens de kindertijd en de adolescentie uitgedragen door drie belangrijke socialiserende actoren: gezin, school en vrienden. Normen worden bepaald voor leeftijd en gender en binnen het gezin; deze normen beïnvloeden het gedrag van jongeren en de mate waarin ze zich aan die normen conformeren, mede geïnspireerd door hun leeftijdsgenoten.

Vanuit deze theoretische achtergrond formuleren we drie concrete onderzoeksvragen:

ov I: Hoe is het gesteld met de digitale geletterdheid van Vlaamse jongeren (I5-I9 jaar)? En in welke mate voorspellen de gangbare sociodemografische kenmer- 
TABEL 1 Leerlingen in de verschillende onderwijsniveaus in \% (Departement Onderwijs en Vorming, 2009)

\begin{tabular}{lll}
\hline & Respondenten onderzoek (N=8I5) & Officieel leerlingenaantal $\mathbf{( N = 2 9 0 . 8 5 6 )}$ \\
\hline ASO & 50,8 & 40,7 \\
TSO & 36,3 & 32,3 \\
BSO & I 2,9 & 24,9 \\
KSO & 0 & $2, \mathrm{I}$ \\
\hline
\end{tabular}

ken (leeftijd, geslacht, opleiding, SES van de ouders) en persoonlijkheidsfactoren (zelfbeeld, risicoperceptie, relatie met ouders) deze digitale geletterdheid?

ov 2: In welke mate voorspellen sociodemografische en persoonlijkheidskenmerken van Vlaamse jongeren de blootstelling aan en beleving van negatieve onlineinhouden van commerciële, agressieve, seksuele of waardegerelateerde aard?

ov 3: Welke coping-strategieën leggen Vlaamse jongeren aan de dag na blootstelling aan dergelijke negatieve online-inhoud? Zijn deze strategieën afhankelijk van het niveau van digitale geletterdheid, de algemene risicoperceptie van de jongeren, hun zelfbeeld en de relatie met hun ouders? Beïnvloedt de interventiestijl van de ouders de coping-strategieën van de jongeren na blootstelling aan negatieve online-inhoud?

\section{Methode}

\section{Dataverzameling en -analyse}

Een schriftelijke vragenlijst werd in de lente van 2009 (februari-april) afgenomen bij 8I5 Vlaamse jongeren in de tweede en derde graad van het middelbaar onderwijs. Negen Vlaamse scholen uit verschillende regio's namen deel aan het onderzoek. De leerlingen werd gevraagd om de vragenlijst in de klas in te vullen. Het aantal respondenten per deelnemende school varieert van 29 (3,5\%) tot I59 leerlingen (I9,5\%). De gemiddelde leeftijd is $\mathrm{I} 6,57$ jaar $(\mathrm{SD}=\mathrm{I}, 24)$. De onderzoeksgroep bestaat uit 50,1\% jongens en 49,9\% meisjes. Hoewel ernaar gestreefd werd om scholen van alle onderwijsniveaus op te nemen in het onderzoek, zijn de leerlingen uit het beroepsonderwijs (BSO) ondervertegenwoordigd (zie tabel I). Aan de hand van regressieanalyses werd nagegaan op welke manier de centrale concepten met elkaar samenhangen. Daar waar het meetniveau het niet toeliet om gebruik te maken van regressieanalyses, werd geopteerd om gemiddelde scores tussen twee of meerdere groepen te vergelijken door middel van t-testen en ANOVA-testen. 


\section{Digitale geletterdheid}

We meten het niveau van digitale geletterdheid aan de hand van:

I het totale internetgebruik (vijfpuntsschaal van 'minder dan één keer per week' tot 'meerdere keren per dag');

2 het gebruik van onlinekansen, gemeten door het gebruik na te gaan van diverse internettoepassingen (negen items, op een vijfpuntsschaal van 'minder dan één keer per week', tot 'meerdere keren per dag');

3 zelf ingeschatte internetvaardigheden, gemeten door na te gaan of een persoon zichzelf in staat acht om bepaalde onlinetaken uit te voeren (I5 items, op een dichotome ja/nee-schaal).

Wat betreft het gebruik van internettoepassingen (onlinekansen), onderscheiden we twee types van gebruik (na factoranalyse met varimax rotatie; $\mathrm{df}=2 \mathrm{I}$; $\mathrm{p}<\mathrm{O}, \mathrm{OO} \mathrm{I}$ ) (Cronbach's $\alpha=0,67$ ). De items 'online shoppen' en 'informatie voor school opzoeken' werden geschrapt uit de analyse omdat ze op meer dan één factor laadden:

I Gebruik van toepassingen gericht op actief zoeken naar entertainment en nieuwe/onbekende inhouden of contactpersonen (muziek downloaden, films/ series downloaden, chatten in chatrooms, spelletjes spelen en foto's posten).

2 Gebruik van toepassingen gericht op communicatie met (voornamelijk) bekende contactpersonen (e-mailen en instant messaging).

Wat betreft de zelf ingeschatte internetvaardigheden, onderscheiden we drie types van vaardigheden (na factoranalyse met varimax rotatie; $\mathrm{df}=\mathrm{I} 5$; $\mathrm{p}<\mathrm{O}, \mathrm{O} \mathrm{OI}$ ) (Cronbach's $\alpha=0,76)$. De items 'e-mail verzenden', 'brief typen' en 'informatie opzoeken' werden geschrapt uit de analyse omdat ze op meer dan één factor laadden:

I Vaardigheden gericht op het gebruik van toepassingen voor sociale communicatie (chatten met instant messengers, chatten met webcam, foto's posten, muziek en afbeeldingen downloaden, profiel aanmaken op sociale netwerksite).

2 Vaardigheden in verband met software (software installeren, berichten op fora plaatsen, software downloaden).

3 Vaardigheden om zelf inhoud te creëren (website maken, blog aanmaken, computer hacken).

\section{Onlinerisico's}

In hun drieledige risicomodel (dat van de zgn. drie C's) maken Staksrud \& Livingstone (2009) onderscheid tussen contentrisico's (kind als ontvanger), contactrisico's, (kind als deelnemer) en conductrisico's (kind als actor). In dit artikel richten we ons uitsluitend op de contentrisico's, met name risico's verbonden aan het ontvangen van online-inhoud (bijv. via website, e-mail, chatbericht). Binnen elk risicodomein onderscheiden Staksrud \& Livingstone vervolgens vier types risico's:

I commerciële risico's: ontvangen van spam en (ongewenste) reclame; 
2 agressieve risico's: ontvangen van gewelddadige, gruwelijke of haatdragende inhouden;

3 seksuele risico's: ontvangen van pornografisch materiaal;

4 waardegerelateerde risico's: online-inhoud die foutieve en/of gevaarlijke informatie en advies bevat over thema's zoals racisme, zelfmoord, anorexia, enzovoort.

De respondenten werd concreet gevraagd om aan te geven of ze al ooit ongevraagde e-mails met reclame hebben ontvangen (nl. commerciële risico's), op een website met pornografisch materiaal zijn terechtgekomen (nl. seksuele risico's), op een gewelddadige site met gruwelijke foto's zijn terechtgekomen (nl. agressieve risico's), en op een racistische site of een zelfmoordsite zijn terechtgekomen (nl. waardegerelateerde risico's). Bij de vraag over spam werd de respondenten een dichotome ja/ nee-schaal voorgelegd. Bij de overige vragen moesten de respondenten aangeven of zij ooit in contact zijn gekomen met dergelijke websites, en zo ja, op welke manier (toevallig, bewust, via junkmail of via een doorgestuurde link).

\section{Coping-strategieën}

Vroeg of laat komen jongeren online in contact met risicovolle inhouden. De reactie op deze (negatieve) ervaringen zijn heel uiteenlopend; jongeren kunnen het probleem negeren of erop ingaan. Het is deze aanpak, namelijk de strategieën die jongeren gebruiken om met bovengenoemde onlinerisico's om te gaan en zich ertegen te beschermen, die we onderzoeken. Jongeren kunnen enerzijds preventieve maatregelen nemen, voordat ze feitelijk in contact komen met ongewenste inhouden al bepaalde acties ondernemen om zich ertegen te beschermen, zoals een spamfilter instellen. Anderzijds kan men al dan niet reageren na een negatieve ervaring; in dat geval gaat het om reactieve maatregelen, zoals het onmiddellijk verlaten van een website. De acties die een jongere onderneemt kunnen ofwel zelfregulerend zijn, ofwel communicatief. Met zelfregulerend duiden we op strategieën waar anderen niet bij betrokken worden, zoals beslissen om al dan niet terug te keren naar een bepaalde website. We spreken van een communicatieve strategie als de jongere ervoor kiest om de ervaring te bespreken met een leeftijdsgenoot en/of een volwassene.

Meteen na de vraag over het contact met bepaalde risicovolle websites werd aan de respondenten gevraagd wat ze gedaan hebben de laatste keer dat zij met een dergelijke website in contact zijn gekomen (keuzemogelijkheden: wegklikken, eerst kijken en dan pas wegklikken, op een later moment naar de bewuste website teruggaan, de link doorsturen, erover praten met een leeftijdsgenoot of met een volwassene).

\section{Tussenkomst ouders}

Ouders kunnen op verschillende manieren een invloed (proberen) uit te oefenen op het internetgebruik van hun kinderen. Om na te gaan of ouders raadgevend dan wel 
controlerend optreden, wordt aan de kinderen een lijst van zeven stellingen voorgelegd waarop zij kunnen aangeven of de uitspraak nooit, zelden, soms of vaak op hen van toepassing is. Na factoranalyse (met varimax rotatie; $\mathrm{df}=\mathrm{I} 5$; $\mathrm{p}<\mathrm{O}, \mathrm{O} \mathrm{O}$ ) (Cronbach's $\alpha=0,66$ ) hebben we het item 'mijn ouders geven me tips om internet beter te gebruiken' geschrapt uit de analyse omdat het op meer dan één factor laadde. De volgende twee types interventiestijlen werden meegenomen in de analyse:

I raadgevend optreden (tonen hoe interessante websites te vinden, leren hoe internet te gebruiken, wijzen op de risico's van internet);

2 controlerend optreden (tijdsduur beperken, bezochte websites controleren, actief toezicht uitoefenen tijdens het computergebruik).

Om na te gaan op welke manier ouders regulerend (restrictief) optreden, werd aan de respondenten een lijst van acht mogelijke beperkingen op hun internetgebruik voorgelegd en werd gevraagd op een ja/nee-schaal aan te geven of hun ouders daarop een verbod hadden ingesteld. $\mathrm{Na}$ factoranalyse (met varimax rotatie; $\mathrm{df}=2 \mathrm{I}$; $\mathrm{p}<0,00 \mathrm{I})$ (Cronbach's $\alpha=0,65$ ) werd het item 'ik mag geen dingen kopen op het internet' geschrapt uit de analyse omdat het onvoldoende laadde op de factoren. Uit de factoranalyse blijkt dat ouders enerzijds regels opleggen in verband met contacten die het kind mag leggen via het internet en anderzijds regels opleggen in verband met het gebruik van internet voor ontspanning:

I restrictief optreden qua contacten opgedaan via het internet (verbod op doorgifte van persoonlijke informatie, om bepaalde websites te bezoeken, om met vreemden te praten in chatrooms en om iemand te ontmoeten die men kent via het internet);

restrictief optreden qua internet voor entertainmentdoeleinden (verbod om films/muziek te downloaden, om onlinespelletjes te spelen en om internet te gebruiken voor zaken die niet gerelateerd zijn aan schoolwerk).

\section{Resultaten}

\section{Digitale geletterdheid}

Om te beginnen werd het totale internetgebruik onder de loep genomen: $76,4 \%$ van de bevraagde Vlaamse jongeren gebruikt het internet dagelijks tot meerdere keren per dag. Tabel 2 toont aan dat jongeren het vaakst gebruikmaken van communicatietoepassingen zoals instant messaging en e-mails versturen. Entertainmenttoepassingen zoals onlinespelletjes en muziek downloaden volgen op afstand. Foto's posten, films downloaden en online shoppen blijven eerder perifere handelingen.

Wat betreft de zelf ingeschatte internetvaardigheden tekenen drie gebruikstypes zich af (na factoranalyse met varimax rotatie; $\mathrm{df}=66, \mathrm{p}<0,00 \mathrm{I}$ ): vaardigheden in online sociale communicatie $(79 \%)$ en softwarevaardigheden (74\%) zijn hierbij 
TABEL 2 Overzicht gebruik internettoepassingen (onlinekansen) \% (N=805)

\begin{tabular}{llllll}
\hline & $\begin{array}{l}\text { < I keer per } \\
\text { week }\end{array}$ & $\begin{array}{l}\text { I keer per } \\
\text { week }\end{array}$ & $\begin{array}{l}\text { > I keer per } \\
\text { week }\end{array}$ & \multicolumn{2}{c}{$\begin{array}{c}\text { Dagelijks > I keer per } \\
\text { dag }\end{array}$} \\
\hline E-mail versturen & 9,4 & 7,I & $3 \mathrm{I}, 4$ & 38,8 & $\mathrm{I} 3,3$ \\
Online shoppen & 96,0 & 2,2 & I,O & 0,6 & 0,3 \\
Informatie voor school opzoeke & 24,6 & 25,3 & 40,4 & 7,6 & $2, \mathrm{I}$ \\
Muziek downloaden & 26,3 & 20,0 & $3 \mathrm{I}, 9$ & $\mathrm{I} 4,2$ & 7,6 \\
Film/serie downloaden & 68,9 & I0,4 & I2,0 & 5,0 & 3,6 \\
Instant messaging & $\mathrm{I} 4,3$ & 5,9 & 25,6 & $3 \mathrm{I}, 5$ & 22,7 \\
Chatten in chatrooms & $74, \mathrm{I}$ & $7, \mathrm{I}$ & 7,8 & 5,8 & 5,3 \\
Spelletjes spelen & 40,2 & I7,7 & $2 \mathrm{I}, \mathrm{O}$ & $\mathrm{I} 2,7$ & 8,4 \\
Foto's posten & 50,4 & 23,0 & I6,6 & 7,9 & 2,0 \\
\hline
\end{tabular}

beduidend prominenter aanwezig dan vaardigheden op het vlak van contentcreatie (1०\%).

Op zoek naar sociodemografische verschillen binnen onze onderzoeksgroep, stellen we vast dat de digitale geletterdheid bij jongens hoger ligt $(M=3,6)$ dan bij meisjes $(\mathrm{M}=3,2)(\mathrm{t}=6,99 ; \mathrm{df}=800 ; \mathrm{p}<0,00 \mathrm{I})$. Als we naar de hoger gemaakte driedeling qua zelf ingeschatte vaardigheden kijken, scoren jongens hoger dan meisjes op het vlak van softwarevaardigheden $\left(t=6,68 ; d f=7 I_{3}, 6 ; p<0,00 I\right)$ en contentcreatie $(t=5,73$; $\mathrm{df}=795,8 ; \mathrm{p}<\mathrm{O}, \mathrm{OOI})$. De digitale geletterdheid bij Vlaamse jongeren verhoogt met de leeftijd $(\mathrm{F}=6,36 ; \mathrm{df}=\mathrm{I} ; \mathrm{p}<0,05)$. Dit uit zich vooral in een hogere softwarevaardigheid $(\mathrm{F}=\mathrm{II}, \mathrm{O} 8$; $\mathrm{df}=\mathrm{I} ; \mathrm{p}<\mathrm{O}, \mathrm{OOI})$. Tieners uit het beroepsonderwijs beschikken over beduidend minder digitale geletterdheid $(\mathrm{M}=3, \mathrm{I})$ dan hun leeftijdsgenoten uit het algemeen secundair $(M=3,4)$ en technisch onderwijs $(M=3,5) \quad(d f=2 ; p<0,0 \circ \mathrm{I})$. Zo beschikken jongeren die een beroepsopleiding (BSO) volgen over beduidend minder vaardigheden in online sociale communicatie dan jongeren uit het $\mathrm{ASO}(\mathrm{MD}=0,08$; $\mathrm{SE}=0,02$; sig=0,00I) en uit het TSO ( $\mathrm{MD}=0,08 ; \mathrm{SE}=0,02$; sig=0,003). Eenzelfde trend tekent zich af qua softwarevaardigheden van BSo-leerlingen ten opzichte van technisch onderwijs ( $\mathrm{MD}=0, \mathrm{I} 6 ; \mathrm{SE}=0,04$; sig=0,000) en algemeen secundair onderwijs ( $\mathrm{MD}=0, \mathrm{I} 6 ; \mathrm{SE}=0,04$; sig=0,000). Op het vlak van vaardigheden in contentcreatie scoren de leerlingen uit het technisch onderwijs naar eigen inschatting hoger dan hun leeftijdsgenoten uit het algemeen secundair onderwijs (MD=०,०7; $\mathrm{SE}=0,02$; sig=0,009). Noch opleidingsniveau noch beroep van vader of moeder blijken verband te houden met de digitale geletterdheid van hun kinderen; wel blijkt het beroep van de vader in zoverre bepalend dat wanneer de vader niet werkt, de groep van zonen of dochters met een gemiddelde of lage geletterdheid groter is $(6 \mathrm{I}, \mathrm{I} \%)$ dan wanneer de vader wel werkt $(43,4 \%)$, en dit ongeacht de beroepsgroep. 
Als we dieper ingaan op het gebruik van onlinekansen, komt aan het licht dat jongens meer fervente gebruikers zijn van technologie ten behoeve van entertainment dan meisjes $(t=7, I 6 ; d f=769,7 ; p<0,001)$. Leeftijd speelt hierbij geen rol van betekenis. Als het op het gebruik van toepassingen gericht op communicatie met vertrouwde personen aankomt, zien we geen significante genderverschillen. Leeftijd is hier wel betekenisvol: met de jaren stijgt het gebruik van toepassingen gericht op communicatie $(\mathrm{F}=5, \mathrm{I} 6 ; \mathrm{df}=\mathrm{I} ; \mathrm{p}<0,05)$. Opleiding blijkt tevens een belangrijke beïnvloeder: leerlingen uit het algemeen secundair onderwijs maken beduidend minder vaak gebruik van de entertainmenttoepassingen ( $\mathrm{MD}=0,25 ; \mathrm{SE}=0, \mathrm{IO}$; sig=0,027), maar gaan vaker aan de slag met applicaties voor communicatie met bekenden in vergelijking met hun leeftijdsgenoten uit het beroepsonderwijs ( $\mathrm{MD}=0,33$; $\mathrm{SE}=0, \mathrm{I2}$; sig=0,022). Beroep en opleiding van de ouders spelen geen rol van betekenis voor het gebruik van entertainmenttoepassingen. Variatie in gebruik van applicaties voor communicatie met vooral bekenden hangt wel samen met het beroep van de vader $\chi^{2}=25,4 ; \mathrm{df}=8$; $\left.\mathrm{p}<0,00 \mathrm{I}\right)$. Wat opvalt, is dat als de vader niet werkt, de zoon of dochter neigt naar een geringer gebruik van technologie voor communicatiedoeleinden met vooral bekenden dan hun leeftijdsgenoten met werkende ouders. Jongeren met laagopgeleide ouders maken beduidend minder gebruik van technologie gericht op communicatie met vooral bekende contacten dan hun leeftijdsgenoten met hoog opgeleide ouders ( $\mathrm{MD}=0,36 ; \mathrm{SE}=0, \mathrm{I} 4 ; \mathrm{sig}=0,040)$.

Op het vlak van persoonskenmerken is gebleken dat het niveau van digitale geletterdheid van Vlaamse tieners positieve samenhang vertoont met het zelfbeeld/zelfvertrouwen (zeven items, Cronbach's $\alpha=0,8 \mathrm{I}$ ) ( $\mathrm{F}=\mathrm{II}, 4 ; \mathrm{df}=\mathrm{I} ; \mathrm{p}<\mathrm{O}, \mathrm{OOI}$ ). Jongeren met een positief zelfbeeld en veel zelfvertrouwen maken beduidend meer gebruik van technologie gericht op entertainment en nieuwe contacten $(\mathrm{F}=\mathrm{I} 4, \mathrm{I} ; \mathrm{df}=\mathrm{I} ; \mathrm{p}<\mathrm{O}, \mathrm{OO} \mathrm{I})$ en geven een hoger niveau aan van contentcreatie $(\mathrm{F}=3,7 ; \mathrm{df}=2 ; \mathrm{p}<0,05)$. Toepassingen gericht op bestaande contacten worden niet verschillend ingezet afhankelijk van zelfbeeld/zelfvertrouwen. De variatie in de perceptie van het internet als veilige omgeving en de mate waarin men zich zorgen maakt over veiligheid op het internet heeft dan weer geen impact op het niveau van digitale geletterdheid. De relatie met hun ouders, tot slot, beïnvloedt evenmin aantoonbaar de digitale geletterdheid van Vlaamse tieners. Een goede relatie met de ouders hangt wel samen met een geringere mate van gebruik van toepassingen gericht op entertainment en potentieel risicovolle nieuwe contacten dan jongeren met een slechte $(\mathrm{MD}=0,38 ; \mathrm{SE}=0, \mathrm{I2}$; $\operatorname{sig}=0,0 \mathrm{IO})$ of een normale ouderband ( $\mathrm{MD}=0, \mathrm{I} 4 ; \mathrm{SE}=0,05$; sig=0,023).

Samengevat kunnen we stellen dat meisjes en leerlingen uit het beroepsonderwijs lager scoren op digitale geletterdheid. Als we het opnemen van digitale kansen van naderbij bekijken, zien we dat jongens, leerlingen uit het beroepsonderwijs, tieners met veel zelfvertrouwen en kinderen die slecht overeenkomen met hun ouders zich meer richten op entertainmenttoepassingen. Oudere tieners (I8-I9 jaar), leerlingen 


\begin{tabular}{|c|c|c|c|c|}
\hline & $\begin{array}{l}\text { Commerciële risico's } \\
(\mathrm{M}=2, \mathrm{I})(\mathrm{SD}=0,64)\end{array}$ & $\begin{array}{l}\text { Agressieve risico's } \\
(\mathrm{M}=\mathrm{I}, 5)(\mathrm{SD}=0,66)\end{array}$ & $\begin{array}{l}\text { Seksuele risico's } \\
(\mathrm{M}=2,0)(\mathrm{SD}=0,88)\end{array}$ & $\begin{array}{l}\text { Waardegerelateerde } \\
\text { risico's }(\mathrm{M}=\mathrm{I}, 2) \\
(\mathrm{SD}=0,5 \mathrm{I})\end{array}$ \\
\hline $\begin{array}{l}\text { Geen/weinig bloot- } \\
\text { stelling }\end{array}$ & I28 (I5,7\%) & $488(59,9 \%)$ & $3 \mathrm{I} 6(38,8 \%)$ & $675(82,8 \%)$ \\
\hline $\begin{array}{l}\text { Gemiddelde bloot- } \\
\text { stelling }\end{array}$ & $478(58,7 \%)$ & $253(31 \%)$ & I8० $(22, \mathrm{I} \%)$ & IO2 (I2,5\%) \\
\hline Veel blootstelling & $209(25,6 \%)$ & 74 (9,1\%) & 3I9 $(39,1 \%)$ & $38(4,7 \%)$ \\
\hline Totaal & 8I5 (I00\%) & 8I5 (I00\%) & 8I5 (I00\%) & 8I5 (I00\%) \\
\hline
\end{tabular}

uit het ASO en kinderen uit hogere socio-economisch gezinnen lijken meer geneigd gebruik te maken van communicatiekansen.

\section{Onlinerisico's}

De overgrote meerderheid van de jongeren $(84,3 \%)$ komt regelmatig tot vaak in contact met commerciële risico's. Ongeveer zes op tien jongeren komen via het internet regelmatig tot vaak in contact met seksuele inhoud. Van degenen die in contact komen met porno, gebeurt dat in de meerderheid van de gevallen op (zeer) regelmatige basis. Blootstelling aan agressieve inhouden komt minder frequent voor: ongeveer drie op tien jongeren krijgen er regelmatig mee te maken en nog eens ongeveer één op tien komt er vaak mee in contact. Omdat de frequente blootstelling eerder beperkt is, kunnen we veronderstellen dat de impact van agressieve inhouden op attitudes ten aanzien van agressie gering zal zijn. Toch kan één bepaald (gruwelijk) beeld een sterke indruk nalaten, zeker op jonge leeftijd. Contact met waardegerelateerde risico's komt relatief weinig voor. Meer dan acht op tien jongeren zijn er nog niet of slechts zelden mee in aanraking gekomen.

Jongens zijn significant vaker blootgesteld aan alle types risico's dan meisjes. De verschillen zijn het meest uitgesproken bij agressieve inhouden ( $\mathrm{t}=\mathrm{I} 8, \mathrm{I} ; \mathrm{df}=730,95$; $\mathrm{p}<0,00 \mathrm{I})$ en bij seksuele inhouden ( $\mathrm{t}=\mathrm{I} 6,8$; $\mathrm{df}=79 \mathrm{I}, 05$; $\mathrm{p}<0,00 \mathrm{I})$. Oudere tieners, voornamelijk de I8- tot I9-jarigen, hebben significant vaker te maken met seksuele inhoud ( $\mathrm{F}=2 \mathrm{I}, 9$; $\mathrm{df}=\mathrm{I} ; \mathrm{p}<\mathrm{O}, \mathrm{OO} \mathrm{I})(\mathrm{MD}=0,42 ; \mathrm{SE}=0,07$; $\mathrm{sig}=0,000)$ en waardegerelateerde inhoud $(\mathrm{F}=5,8 ; \mathrm{df}=\mathrm{I} ; \mathrm{p}<0,050)(\mathrm{MD}=0, \mathrm{I} 5 ; \mathrm{SE}=0,06$; sig=0,037) dan jongere tieners. Jongeren uit het TSO krijgen significant vaker te maken met agressieve $(\mathrm{F}=70,94 ; \mathrm{df}=2 ; \mathrm{p}<0,00 \mathrm{I})$, seksuele $(\mathrm{F}=\mathrm{IO}, \mathrm{IO} ; \mathrm{df}=2 ; \mathrm{p}<0, \mathrm{O} \mathrm{I})$ en waardegerelateerde risico's (Welch $=6,3$; $\mathrm{df}=266,9$; $\mathrm{p}<\mathrm{O}, \mathrm{OI}$ ). De verschillen in blootstelling tussen leerlingen uit het TSO en de andere opleidingsniveaus zijn het meest uitgesproken voor agressieve en seksuele inhouden. We merken hierbij op dat jongeren, en vooral jongens, uit het TSO een sterker zelfbeeld hebben $\left.\chi^{2}=25,9 ; \mathrm{df}=4, \mathrm{p}<0,00 \mathrm{I}\right)$ en over een 
TABEL 4 Gebruik van verschillende types strategieën

\begin{tabular}{|c|c|c|c|c|c|}
\hline $\begin{array}{l}\text { Preventief/zelfregu- } \\
\text { lerend }\end{array}$ & Frequentie (\%) & $\begin{array}{l}\text { Reactief/zelfregu- } \\
\text { lerend }\end{array}$ & Frequentie (\%) & $\begin{array}{l}\text { Reactief/communi- } \\
\text { cerend }\end{array}$ & Frequentie (\%) \\
\hline Beperkte coping & I35 (I6,8\%) & Geen coping & $63(16,6 \%)$ & Geen coping & $362(46,2 \%)$ \\
\hline Gemiddelde coping & $4 \mathrm{I} 7(5 \mathrm{I}, 9 \%)$ & Beperkte coping & $262(68,9 \%)$ & Beperkte coping & $313(39,9 \%)$ \\
\hline Sterke coping & $25 \mathrm{I}(3 \mathrm{I}, 3 \%)$ & $\begin{array}{l}\text { Gemiddelde/sterke } \\
\text { coping }\end{array}$ & $55(15,5 \%)$ & $\begin{array}{l}\text { gemiddelde/sterke } \\
\text { coping }\end{array}$ & $\log (\mathrm{I} 3,9 \%)$ \\
\hline Totaal & 803 (го०\%) & & 380 (100\%) & & 784 (І००\%) \\
\hline
\end{tabular}

hogere mate van digitale geletterdheid beschikken $\left(\chi^{2}=29,4 ; \mathrm{df}=4 ; \mathrm{p}<0, \mathrm{O} \mathrm{I}\right)$. Zulke online actieve jongeren met relatief hoge zelf ingeschatte digitale vaardigheden hebben vaker te maken met alle types van onlinerisico's, zowel commercieel $(\mathrm{F}=20,8$; $\mathrm{df}=2 ; \mathrm{p}<\mathrm{O}, \mathrm{OOI}$ ), agressief (Welch=3I,3; $\mathrm{df} \mathrm{I}=2 ; \mathrm{df} 2=80,4)$, seksueel $(\mathrm{F}=22,4 ; \mathrm{df}=2$; $\mathrm{p}<0, \mathrm{O} \mathrm{I})$ als waardegerelateerd (Welch $\left.=\mathrm{I} 2,4 ; \mathrm{df}=2 ; \mathrm{df}_{2}=82 ; \mathrm{p}<0,00 \mathrm{I}\right)$. Dit wijst erop dat intensieve activiteit op het internet (veel gebruik) samengaat met meer blootstelling aan onlinerisico's (veel risico's).

Kinderen met laagopgeleide ouders komen vaker in contact met risicovolle, agressieve $(\mathrm{F}=4,5 ; \mathrm{df}=2 ; \mathrm{p}<0,050)(\mathrm{MD}=0,2 \mathrm{I} ; \mathrm{SE}=0,07 ;$ sig=0,008), seksuele $(\mathrm{F}=3, \mathrm{I} ; \mathrm{df}=2$; $\mathrm{p}<0,05)(\mathrm{MD}=0,28 ; \mathrm{SE}=0, \mathrm{II} ; \mathrm{sig}=0,04 \mathrm{I})$ en waardegerelateerde inhoud (Welch=6,8; $\left.\mathrm{dfI}=2 ; \mathrm{df}_{2}=\mathrm{I} 30,9 ; \mathrm{p}<\mathrm{O}, \mathrm{OI}\right)(\mathrm{MD}=0,38 ; \mathrm{SE}=0, \mathrm{II} ; \mathrm{sig}=0,002)$. We stellen vast dat kinderen van laagopgeleide ouders vaker ofwel een sterk zelfbeeld ofwel een laag zelfbeeld hebben $\left(\chi^{2}=32,9 ; \mathrm{df}=4 ; \mathrm{p}<0, \mathrm{O} \mathrm{I}\right)$ en bovendien vaker een slechte relatie hebben met hun ouders $\left(\chi^{2}=54,2 ; \mathrm{df}=4 ; \mathrm{p}<\mathrm{O}, \mathrm{OOI}\right)$. Jongeren die over veel zelfvertrouwen beschikken, hebben op het internet vaker te maken met agressieve $(\mathrm{F}=5,7$; $\mathrm{df}=2$; $\mathrm{p}<\mathrm{O}, \mathrm{OI})$ en seksuele inhoud $(\mathrm{F}=8, \mathrm{I} ; \mathrm{df}=2 ; \mathrm{p}<\mathrm{O}, \mathrm{OOI})$. Wat betreft waardegerelateerde inhoud (Welch $=4,7 ; \mathrm{df}=2 ; \mathrm{df}_{2}=64 ; \mathrm{p}<0,050$ ), stellen we vast dat de jongeren met een normaal zelfbeeld hier het minst mee te maken krijgen. Als de relatie met de ouders goed is, komen jongeren minder vaker in contact met agressieve (Welch=8,6; dfI=2; df2=I79,9; $\mathrm{p}<0,00 \mathrm{I})$ seksuele $(\mathrm{F}=3,6 ; \mathrm{df}=\mathrm{I} ; \mathrm{p}<0,050)$ en waardegerelateerde inhoudsrisico's (Welch $\left.=\mathrm{I} 4,6 ; \mathrm{df}_{\mathrm{I}}=2 ; \mathrm{df}_{2}=\mathrm{I} 75,9 ; \mathrm{p}<\mathrm{O}, \mathrm{OOI}\right)$. Een goede ouder-kindrelatie staat los van het al dan niet actief tussenkomen in het internetgebruik van de kinderen, maar lijkt wel een meer beperkt contact met onlinerisico's op te leveren.

\section{Strategieën om met onlinerisico's om te gaan}

We stellen vast dat jongeren het vaakst kiezen voor preventieve/zelfregulerende strategieën bij het omgaan met risico's op het internet (zie tabel 4). De grote meerderheid van de jongeren $(83,2 \%)$ gaat gemiddeld tot sterk preventief te werk door 
bijvoorbeeld niet in te gaan op e-mails met reclame en zich kritisch op te stellen ten aanzien van bedrijven/organisaties die persoonlijke gegevens vragen.

Reactieve en zelfregulerende strategieën worden het meest in beperkte mate gehanteerd. Als jongeren in contact komen met ongewenste inhoud, zal 32\% (zelfmoord) tot $42 \%$ (geweld) van de jongeren de website (even) bekijken, en dan voorgoed verlaten. Circa $20 \%$ (zelfmoord) tot $28 \%$ (geweld en racisme) van de jongeren zal de website onmiddellijk verlaten. Strategieën zoals later teruggaan naar de website en de link/foto's doorsturen naar anderen komen veel minder vaak voor (minder dan I०\%).

Jongeren zijn het minst geneigd om met anderen te praten na een negatieve ervaring op het internet: iets minder dan de helft praat daar helemaal nooit met iemand over. Zeer weinig jongeren gaan een gesprek aan met een volwassene: dit varieert van 9,3\% voor racisme tot 13,I\% die over porno praat met ouders en/of leerkracht. Met leeftijdsgenoten wordt er vooral over porno gepraat $(44,4 \%)$. Over andere, risicovolle inhouden zoals geweld $(\mathrm{I} 2,4 \%)$, racisme $(\mathrm{II}, 2 \%)$ en zelfmoord $(8,3 \%)$ wordt er opvallend minder met leeftijdsgenoten gesproken.

De risicoperceptie lijkt enkel een impact te hebben op het gebruik van preventieve/ zelfregulerende strategieën. Jongeren met een lage risicoperceptie zijn sterker geneigd om preventieve/zelfregulerende strategieën te hanteren $(\mathrm{F}=6,7 ; \mathrm{df}=2$; $\mathrm{p}<0,050)$. Als de relatie met de ouders slecht is, hanteren jongeren significant meer reactieve/zelfregulerende strategieën $(\mathrm{F}=3,0 ; \mathrm{df}=2 ; \mathrm{p}<0,050) \quad(\mathrm{MD}=0, \mathrm{II} ; \mathrm{SE}=0,45$; sig $=0,048$ ). Dit houdt in dat ze in vergelijking met jongeren die een goede relatie hebben met hun ouders vaker zelfstandig maatregelen nemen om in de toekomst beter te kunnen omgaan met ongewenste inhouden, zonder daarbij een gesprek aan te gaan met iemand. Daarnaast stellen we vast dat jongeren die een slechte relatie hebben met hun ouders vaker een leerkracht in vertrouwen zullen nemen om te praten over een slechte online-ervaring dan jongeren die goed overeenkomen met hun ouders $\left(\chi^{2}=26,4 ; \mathrm{df}=2 ; \mathrm{p}<0, \mathrm{OOI}\right)$.

\section{Tussenkomst van de ouders}

Ouders kunnen raadgevend, controlerend of restrictief optreden inzake het internetgebruik van hun kinderen. Kinderen van ouders die nooit of zelden raad geven $(\mathrm{M}=2,4 / \mathrm{SD}=0,63)$ zijn geneigd om meer te kiezen voor preventieve/zelfregulerende strategieën dan kinderen die thuis gemiddeld of veel raad krijgen $(\mathrm{M}=2,2 / \mathrm{SD}=0,66)$ $(t=2, \mathrm{I} ; \mathrm{df}=800 ; \mathrm{p}<0,050)$. Als het gaat om communicatieve strategieën, lijkt een controlerende aanpak enkel invloed te hebben op praten over geweld, racisme of zelfmoord op het internet $\left(\alpha^{2}=4,9 ; \mathrm{df}=\mathrm{I} ; \mathrm{p}<0,050\right)$. Het betreft hier bovendien enkel communicatie met leeftijdsgenoten $\left(\chi^{2}=5,0 ; \mathrm{df}=\mathrm{I} ; \mathrm{p}<0,050\right)$, hetgeen betekent dat kinderen die sterk gecontroleerd worden door hun ouders hieromtrent vaker naar hun leeftijdsgenoten stappen maar niet naar de ouders of leerkracht. Als ouders geen tot weinig regels opleggen in verband met het gebruik van internet voor (sociale) contacten, zullen hun kinderen vaker de stap zetten om met leeftijdsgenoten te 
praten over risicovolle inhoud op het internet $\left(\chi^{2}=6,5 ; \mathrm{df}=\mathrm{I} ; \mathrm{p}<0,050\right)$. We stellen vast dat het hier enkel om pornosites gaat $\left(\chi^{2}=4,9 ; \mathrm{df}=\mathrm{I} ; \mathrm{p}<0,050\right)$. Als de ouders gemiddeld tot veel regels opleggen in verband met het gebruik van internet voor entertainment, zullen kinderen vaker (negatieve) internetervaringen bespreken met een volwassene $\left(\alpha^{2}=5,7 ; \mathrm{df}=\mathrm{I} ; \mathrm{p}<0,050\right)$. Dit geldt enkel voor websites met geweld, racisme of zelfmoord $\left(\chi^{2}=8,05 ; \mathrm{df}=\mathrm{I} ; \mathrm{p}<0,010\right)$.

\section{Discussie en conclusie}

Een intensiever internetgebruik, een breder gebruik van internettoepassingen (onlinekansen), en een hogere mate van zelf ingeschatte internetvaardigheden betekent meer potentiële blootstelling aan alle types risico's. Dit kan verklaren waarom Vlaamse jongens en de oudste leeftijdsgroep (I8- tot I9-jarigen) opvallend vaker te maken hebben met internetrisico's dan meisjes en jongere tieners. Opmerkelijk is de rol van zelfbeeld: zelfzekere tieners maken vaker gebruik van internet om nieuwe dingen te ontdekken en ervaren meer blootstelling aan risicovolle inhoud. Mogelijk hebben deze jongeren sterker de behoefte om zichzelf uit te dagen door zich bloot te stellen aan potentieel choquerende inhouden. De mate van zelfvertrouwen ligt hoger bij jongens en leerlingen uit het technisch onderwijs (TSO): zij blijken ook actiever bezig te zijn met het internet en zijn vaker blootgesteld aan internetrisico's dan meisjes en leerlingen uit de andere opleidingsniveaus. Ouders doen er daarom goed aan te investeren in een vertrouwensrelatie met hun opgroeiende tieners: tieners met een goede ouderband zijn immers minder actief qua gebruik van entertainmenttoepassingen (hoewel we hier de mogelijk positieve cognitieve impact van dergelijke toepassingen niet willen onderschatten), komen minder in contact met risicovolle inhouden en gaan minder over tot het leggen van contacten via internet.

Vlaamse tieners uit minder gegoede middens en leerlingen uit het beroepsonderwijs gebruiken technologie het minst ter instandhouding of bevordering van hun sociale contacten. Dus tieners met reeds geringere mogelijkheden qua sociaal kapitaal en beperkte studeercapaciteiten maken naar verhouding nog het minst gebruik van technologie om contacten te leggen. Toch blijkt dat kinderen van laagopgeleide ouders in verhouding meer blootstelling aan potentieel risicovolle inhouden ervaren. In tegenstelling tot de algemene trend, lijkt in minder gegoede gezinnen laag gebruik bovendien samen te gaan met hoge risico's. Laagopgeleide ouders zijn vaak minder vertrouwd met computers en internet. Dit kan leiden tot meer onzekerheid inzake regulering en begeleiding van het internetgebruik van hun kinderen en tot een onderschatting van de onlinerisico's waarmee hun kinderen geconfronteerd kunnen worden.

Vlaamse jongeren worden het vaakst blootgesteld aan commerciële risico's. Sociodemografische en persoonlijkheidsfactoren hebben hier weinig of geen impact op. 
Deze factoren vertonen wel een matige tot sterke samenhang met blootstelling aan agressieve, seksuele en waardegerelateerde inhouden. Commercieelgetinte inhouden zijn doorgaans minder choquerend, waardoor jongeren zich mogelijk niet meteen realiseren dat ze reële privacyrisico's en/of financiële risico's kunnen lopen. Meer frequente blootstelling kan daarom waarschijnlijker worden. In het geval van porno lijkt het erop dat een eerste contact met pornografisch materiaal vaak resulteert in frequente blootstelling. Jongeren kunnen na een eerste contact ofwel bewust op zoek gaan naar meer porno, ofwel verschijnen pornografische beelden daarna vaker (ongevraagd) op het scherm via bijvoorbeeld pop-ups of spam.

De meeste jongeren hanteren al een aantal preventieve strategieën om zichzelf te beschermen tegen mogelijke risico's op het internet. Vooral jongeren die thuis weinig raad krijgen en het internet als veilig percipiëren, lijken vaker preventief op te treden. Reactieve maatregelen worden door de meesten slechts in beperkte mate genomen. Jongeren zijn (zeer) weinig geneigd om na contact met risicovolle inhoud daarover te communiceren met anderen, behalve als het gaat om praten over porno met leeftijdsgenoten. Opvallend is dat zelfbeeld geen impact blijkt te hebben op het gebruik van strategieën om met internetrisico's om te gaan. Jongeren die een slechte relatie hebben met hun ouders, lijken meer actie te ondernemen na contact met risicovolle inhoud, al dan niet om blootstelling in de toekomst te vermijden. Mogelijk nemen deze jongeren ook in andere situaties een zelfstandigere houding aan omdat zij minder het gevoel hebben bij hun ouders terecht te kunnen, en grijpen zij daarom sneller in als er zich een probleem voordoet. De tussenkomst van de ouders heeft geen eenduidige impact op de strategieën die de kinderen aanwenden om te leren omgaan met risico's op het internet. Naargelang de aard van het risico (porno, geweld, racisme of zelfmoord), gaan jongeren een heel andere communicatiestrategie hanteren (bijv. als de ouders geen restricties opleggen inzake internetgebruik voor sociale communicatie, zijn de kinderen meer geneigd om te praten met leeftijdsgenoten over pornografie, maar niet over andere types van risicovolle inhoud).

In een informatiemaatschappij is digitale inclusie van groot belang wil men als burger volwaardig kunnen participeren aan het maatschappelijk leven. Daarom is het belangrijk om jongeren te motiveren gebruik te maken van het brede scala aan kansen en voordelen die het internet te bieden heeft, zodat ze kunnen evolueren van kinderen die informatie opzoeken voor een schooltaak en computerspelletjes spelen tot jongeren die actief deelnemen aan onlinediscussies en zelf hun mening formuleren op hun eigen blog of website. Deze stappen naar een meer complex internetgebruik gaan idealiter gepaard met de ontwikkeling van vaardigheden om uit de veelheid van online-informatie relevante content te selecteren en deze kritisch te evalueren. Jongeren moeten leren zich kritisch op te stellen en zich bewust worden van de mogelijke risico's op het internet, zoals onbetrouwbare of misleidende informatie en choquerende inhouden. Op die manier kunnen ze gepaste strategieën ont- 
wikkelen, zodat zij met dergelijke beelden leren omgaan en in staat zijn om desgewenst gelijkaardig contact in de toekomst te vermijden.

We concluderen dat de digitale inclusie van Vlaamse jongeren eveneens gradueel verloopt; jongeren zijn duidelijk vaardiger qua toepassingen voor informatievergaring, entertainment en communicatie dan qua contentcreatie. De vaststelling dat jongeren die ofwel een laag zelfbeeld, ofwel een hoog zelfbeeld meer blootstelling aan onlinerisico's ervaren, kan wijzen op een verschil in motieven (behoeften) voor internetgebruik. Erg zelfzekere jongeren gaan mogelijk vaker bewust op zoek naar 'kicks' en uitdagingen in choquerende onlinecontent. Meisjes lijken zich meer te richten op communicatietoepassingen, daar waar jongens meer interesse vertonen in technische aangelegenheden zoals software installeren en computers hacken. Deze verschillen in behoeften kunnen verklaard worden vanuit de uses \& gratifications-theorie. Het belang van de sociale omgeving (socialisatietheorie) blijkt uit de impact van de kwaliteit van de ouder-kindrelatie. De tussenkomst van de ouders lijkt geen eenduidige impact te hebben op de blootstelling aan onlinerisico's bij hun kroost. Toch stellen we vast dat ouders met meer socio-economisch kapitaal het internetgebruik van hun kinderen van dichtbij volgen en neemt de tussenkomst van de ouders aanzienlijk af naarmate de kinderen ouder worden.

Een beperking van dit onderzoek is de te geringe bevraging van jongeren uit het beroepsonderwijs (BSO). Bepaalde strategieën om met internetrisico's om te gaan, zeker de communicatieve strategieën, worden slechts door een beperkt aantal jongeren gehanteerd. Naar de toekomst toe is een evenwichtiger samengestelde steekproef nodig om de bevindingen hieromtrent te kunnen vaststellen en interpreteren. Wat betreft de meting van preventieve/zelfregulerende strategieën, zijn meer diepgaande vragen nodig die meer specifiek gericht zijn op agressieve, seksuele en waardegerelateerde risico's. In dit artikel werd enkel ingegaan op de zogenaamde contentrisico's. Er werden in dezelfde survey eveneens gegevens rond contact en conductrisico's bij Vlaamse jongeren verzameld. In latere publicaties zal hierop dieper ingegaan worden, met als doel een totaalbeeld te krijgen van de blootstelling aan de drie onlinerisicodomeinen. In vervolgonderzoek zijn we van plan om de publiekskenmerken te onderwerpen aan een meer modelmatige toetsing, waarbij aan de hand van multivariate analyses de mediërende verbanden tussen de verschillende factoren blootgelegd worden. Dit zal gebeuren in het tweede deel van het EU Kids Online-onderzoek. In het voorjaar van 20 Io wordt een vragenlijst afgenomen bij 25.000 kinderen en hun ouders in 25 Europese landen, waaronder ook België en Nederland. De eerste bevindingen kunnen worden verwacht tegen september 20 Io. 


\section{Literatuur}

Broos, A. \& Roe, K. (2006). The digital divide in the playstation generation: self-efficacy, locus of control and ICT-adoption among adolescents. Poetics, 34(4/5), pp. 306-3I7.

Departement Onderwijs \& Vorming. Stafdiensten (2008). Statistisch jaarboek van het Vlaams Onderwijs, schooljaar 2007-2008. Vlaams Ministerie van onderwijs en vorming.

Europese Commissie (2006). Safer Internet, Special Eurobarometer 250. Safer Internet for Children. Luxemburg: Europese Commissie.

Europese Commissie (2008). Towards a safer use of the internet for children in the EU - a parent's perspective. Flash Barometer Series 248. Luxemburg: Europese Commissie.

Livingstone, S. (2004). Media literacy and the challenge of new information and communication technologies. Communication Review, 1(7), pp. 3-14.

Livingstone, S. \& Helsper, E.J. (2007). Gradations in digital inclusion: children, young people and the digital divide. New Media QX Society, 9(4), pp. 67I-96.

Livingstone, S. \& Helsper, E.J. (2008). Parental mediation of children's internet use. Journal of Broadcasting \& Electronic Media, 52(4), pp. 58I-599.

Livingstone, S. \& Helsper, E.J. (2009). Balancing opportunities and risks in teenagers' use of the internet: the role of online skills and internet self-efficacy. New Media Q Society, 11(8), pp. I-25.

Livingstone, S. \& Haddon, L. (2009). EU Kids Online. Final Report. LSE, Londen: EU Kids Online.

Newhagen, J.E. \& Rafaeli, S. (I996). Why communication researchers should study the internet: a dialogue. Journal of Communication 46(I), pp. 4-I3.

Staksrud, E. \& Livingstone, S. (2009). Children and online risk. Powerless victims or resourceful participants? Information, Communication and Society, 12(3), pp. 364-387.

Tapscott, D. (1998). Growing Up Digital: The rise of the net generation. New York, NY: McGraw-Hill.

Valcke, M., Schellens, T., Van Keer, H. \& Gerarts, M. (2005). Veilig computergebruik thuis en op school. Gent: Universiteit Gent, Departement Onderwijskunde.

Vandercammen, M. (ed.). (2006). Jongeren en de nieuwe technologie. Brussel: OIVO.

Van Dijk, J. (2006). Digital divide research, achievement and shortcomings. Poetics, 34(4/5), pp. 22I-235.

Walrave, M., Lenaerts, S. \& De Moor, S. (2008). Teens \& ICT: Risks and opportunities. Cyberteens @ risk. Antwerpen: Universiteit Antwerpen.

Weiser, E.B. (2000). Gender differences in internet use patterns and internet application preferences, CyberPsychology and Behavior 3(2), pp. I67-77. 